\title{
CD133 positive cells isolated from A549 cell line exhibited high liver metastatic potential
}

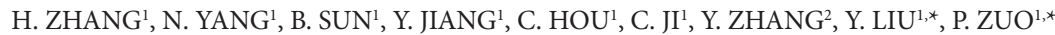

${ }^{1}$ Department of Pharmacology, Institute of Basic Medical Sciences, Chinese Academy of Medical Sciences \& Peking Union Medical College, No.5 Dongdansantiao, Beijing 100005, China; ${ }^{2}$ Department of Pathology, Institute of Basic Medical Sciences, Chinese Academy of Medical Sciences \& Peking Union Medical College, No.5 Dongdansantiao, Beijing, 100005, China.

*Correspondence: pingping_zuo@126.com, liuyanyong@126.com

Received March 23, 2013 / Accepted July 10, 2013

\begin{abstract}
Lung cancer remains a major cause of cancer-related lethality because of high incidence and recurrence in spite of significant advances in staging and therapy. In present study, we identified a subpopulation of cells isolated from the A549 cell line with marker CD133. In vivo results showed that A549 CD133 ${ }^{+}$cells displayed high liver metastatic potential. Severe liver cell damage with tumor cell invasion revealed by pathological examination and these changes were consistent with the results of serological tests where the plasma GPT and GOT level are significantly higher than that of the control group. Compared with A549 cells, A549 CD133+ cells expressed high levels of VEGF and exhibited high migration and invasion capability. In conclusion, we first reported that $\mathrm{A} 549 \mathrm{CD} 133^{+}$cells exhibited characteristic of high liver metastatic potential which makes it be a suitable model for further study of liver metastasis of lung adenocarcinoma and provide a potential platform for antimetastatic drug discovery or evaluation.
\end{abstract}

Key words: human lung adenocarcinoma, liver metastasis, migration, invasion, CD133

Lung cancer is one of the most aggressive neoplasms in the world [1]. Despite management and treatment of lung cancer has been improved these years, but the prognosis remains poor, the 5-year survival rate of non-small cell lung cancer (NSCLC) is no more than $15 \%$ [2]. Approximately $50 \%$ of NSCLC patients with stage I and II will die from recurrent disease despite conventional therapy, and nearly $70 \%$ of lung cancer patients will die from metastatic disease, even after surgical resection of the primary tumor, radiation therapy, and chemotherapy [3]. Thus, it is important to find novel effective therapies to inhibit lung cancer metastasis.

The most common four metastatic sites of patients with solitary metastatic NSCLC were: bone, liver, kidney and spleen [3]. Nevertheless, the mechanism of which lung adenocarcinoma selectively disseminated to certain organs remains unknown. However, experimental reproducible animal models facilitate to understand the process of metastasis and can provide suitable models for basic or preclinical studies.

Different kinds of cancer metastasis model have been published yet. Early in 1996, Iguchi H et al [4] have established lung cancer metastasis model with human lung squamous cell carcinoma-derived cells (HARA). In 1959, Leduc [5] was the first to describe liver metastasis in mice after injection of hepatoma carcinoma cells in the spleen. Moreover, the liver metastasis models in nude mice of colon carcinoma have been successfully established [6,7]. Early studies in immunodeficient mice illustrated that subcutaneous injection of tumor cells seldom give rise to liver metastases [8].

However, no lung adenocarcinoma liver metastasis model has been published so far. CD133 as a marker of cancer stem cells (CSCs) has been demonstrated in many cancers including lung cancer [9-13]. The CSCs theory indicated that subpopulation of tumor cells with stem or progenitor cell characteristics can initiate tumor formation and tumor recurrence and play essential roles in the metastatic spread of primary tumors and drug resistance $[14,15]$.

In our study, we isolated a cell subpopulation expressing CD133 from A549 cell line with high liver metastasis potential which could be implemented by subcutaneous injection. It is the first report on a lung cancer cell line with high liver metastasis character, which could be applicable to establish 
lung cancer metastasis model and also could provide a new method of studying lung cancer metastasis.

\section{Materials and methods}

A549 cells passaged in vivo and cultured in vitro. The human lung adenocarcinoma cell line A549 was obtained from Cell Resource Center of institute of Basic Medical Sciences Chinese Academy of Medical Sciences, School of Basic Medicine Peking Union Medical College (Beijing, China). Male and female BALB/c nude mice, aged 4 weeks, were purchased from the Institute for Laboratory Animal Resources of National Institutes for Food and Drug Control (Beijing, China). Mice were maintained under standard conditions and treated according to the institutional guidelines for animal care. After accommodation to the environment for a week, mice were subcutaneously injected at armpit with A549 cells $\left(1 \times 10^{7}\right)$ suspend in PBS in a volume of $100 \mu$ l. Tumor size was measured with vernier caliper, and tumor volume was calculated as (length $\times$ width $\left.^{2}\right) / 2$. After the tumor volume is greater than $150 \mathrm{~mm}^{3}$, the mice were sacrificed and the tumor was harvest sterilely.

The tumor was cut into pieces with sterilized scissors, and then incubated with $0.25 \%$ trypsin/EDTA at $37{ }^{\circ} \mathrm{C}$ in a humidified $5 \% \mathrm{CO}_{2}$ atmosphere for $15 \mathrm{~min}$. The supernatant was filtered by a 200 mesh sieve and transferred into the centrifuge tube, $800 \times \mathrm{rpm}$ centrifugated for $5 \mathrm{~min}$. The obtained cell were resuspended in the F12 medium and incubated at $37^{\circ} \mathrm{C}, 5 \% \mathrm{CO}_{2}$ atmosphere. F12 medium is supplemented with $10 \%$ fetal bovine serum, $2 \mathrm{mmol} / \mathrm{ml}$ glutamine, $100 \mathrm{U} / \mathrm{ml}$ penicillin and streptomycin. Cells were passaged with $0.25 \%$ trypsin/EDTA every 3-4 days.

A549 $\mathrm{CD} 133^{+}$cell separation. In vivo passaged A549 cells were incubated at $4{ }^{\circ} \mathrm{C}$ with R-phycoerythrin (PE)-conjugated anti-CD133/1(AC133) antibody (Miltenyi Biotec, Auburn, CA, USA) in dark for $20 \mathrm{~min}$ then $4{ }^{\circ} \mathrm{C}$ centrifugated $300 \times \mathrm{g}$ for $10 \mathrm{~min}$. The supernatant was removed and cells were resuspended in $1 \mathrm{ml}$ PBS and filtered by a 200 mesh sieve. Washing steps was repeated and finally the cells were resuspeneded in $1 \mathrm{ml}$ PBS and analyzed by flow cytometry (FACS Aria II; BD Biosciences, Special Order System, USA). CD $133^{+}$cells were sorted using a FACS Aria II cell sorter, gathered and cultured in

Table 1. Primer sequences for real time PCR

\begin{tabular}{ll}
\hline Gene & Sequences 5'-3' $^{\prime}$ \\
\hline VEGF-A & F-AGGGCAGAATCATCACGAAGT \\
& R-AGGGTCTCGATTGGATGGCA \\
VEGF-B & F-GGCTGGCAACATAACAGAGAA \\
& R-CCCCACATCTATACACACCTCC \\
MMP-2 & F-GATACCCCTTTGACGGTAAGGA \\
& R-CCTTCTCCCAAGGTCCATAGC \\
Beta-Actin & F-CATGTACGTTGCTATCCAGGC \\
& R-CTCCTTAATGTCACGCACGAT \\
\hline
\end{tabular}

serum free medium (SFM) consisting of DMEM-F12 medium supplemented with $20 \mathrm{ng} / \mathrm{ml}$ epidermal growth factor (Peprotech, Rocky Hill, NJ, USA), $20 \mathrm{ng} / \mathrm{ml}$ basic fibroblast growth factor (Peprotech, Rocky Hill, NJ, USA), B27 (Invitrogen Life Technologies, Grand island, NY, USA), $2 \mathrm{mmol} / \mathrm{ml}$ glutamine, $100 \mathrm{U} / \mathrm{ml}$ penicillin and streptomycin. Cells were incubated at $37^{\circ} \mathrm{C}$ in a humidified $5 \% \mathrm{CO}_{2}$ atmosphere, passaged with $0.05 \%$ trypsin/EDTA every 3-4 days.

In vitro sphere formation assay. $1 \mathrm{ml} 1.2 \%$ bottom-layer HyAgarose with low melting-point medium (Hydragene Co, Xiamen, China) mixed with equal volume of F12 medium which has a final concentration of $10 \%$ fetal bovine serum, $2 \mathrm{mmol} / \mathrm{ml}$ glutamine, $100 \mathrm{U} / \mathrm{ml}$ penicillin and streptomycin were add into 24-well plates (Costa, corning, NY, USA) and allowed to solidification at room temperature for $2 \mathrm{~h}$.

Cells were plated in 24-well plates at a density of 5000-10000 viable cells $/ \mathrm{ml}$ on the bottom-layer HyAgarose and grown in $0.7 \%$ HyAgarose with low melting point- medium mixed with equal volume of F12 medium which has a final concentration of $10 \%$ fetal bovine serum, $2 \mathrm{mmol} / \mathrm{ml}$ glutamine, $100 \mathrm{U} / \mathrm{ml}$ penicillin and streptomycin. Cells were further allowed to grow at $37^{\circ} \mathrm{C}$ in a humidified $5 \% \mathrm{CO}_{2}$ atmosphere for 21 days and the numbers of spheres were counted by microscope.

In vitro migration and invasion analysis. Cell invasion was evaluated with matrigel-coated Transwell cell culture chambers equipped with a filter membrane with $8 \mu \mathrm{m}$ pores size (Corning Costar, NY, USA). Cell migration was evaluated in the same Transwell cell culture chambers without matrigel. $100 \mu \mathrm{l}$ serum-free DMEM-F12-diluted Matrigel $(5 \mathrm{mg} / \mathrm{mL})$ was added to the Transwell filters of the chambers and incubated at $37^{\circ} \mathrm{C}$ for $2 \mathrm{~h}$ to form a matrix gel. Cells were plated at a density of $1 \times 10^{4}$ cells per well in the upper well of the Transwell chamber. As the chemoattractant, $600 \mu \mathrm{L}$ DMEM-F12 containing $10 \%$ fetal bovine serum was added to the lower chamber. After incubation at $37^{\circ} \mathrm{C}$, in a humidified $5 \% \mathrm{CO}_{2}$ atmosphere for $24 \mathrm{~h}$, non-invasive cells in the upper chamber were removed by wiping with a cotton swab, and invasive cells were fixed with $20 \%$ ethanol and stained with $0.1 \%$ crystal violet in $20 \%$ ethanol. The cells that had invaded across the matrigel and passed through the Transwell filter were counted under a light microscope.

Real-time quantitative PCR. Analysis of mRNA expression of vascular endothelial growth factor A (VEGF-A), VEGF-B and matrix metalloproteinase 2 (MMP-2) were performed by RT-PCR amplification. Total RNA was extracted from the A549 cells and A549 CD133+ cells with TRIzol Reagent (Invitrogen) according to the manufacturer's instruction. cDNA was synthesized from $2 \mu \mathrm{g}$ of RNA using the RNA Transcript kit (Transgen Biotech, Beijing). Real-time quantitative PCR (RTqPCR) was carried out with SYBR Premix Ex Taq ${ }^{\mathrm{TM}}$ (TAKARA Biotechnology, Dalian, China) using the ABI Prism 7500 PCR system (ABI, USA).

The PCR primer sequences are provided in Table 1 . The amplification conditions were $95^{\circ} \mathrm{C}$ for $1 \mathrm{~min}$, followed by 40 cycles of $95^{\circ} \mathrm{C}$ for $20 \mathrm{sec}, 60^{\circ} \mathrm{C}$ for $30 \mathrm{sec}$ and $72{ }^{\circ} \mathrm{C}$ for 

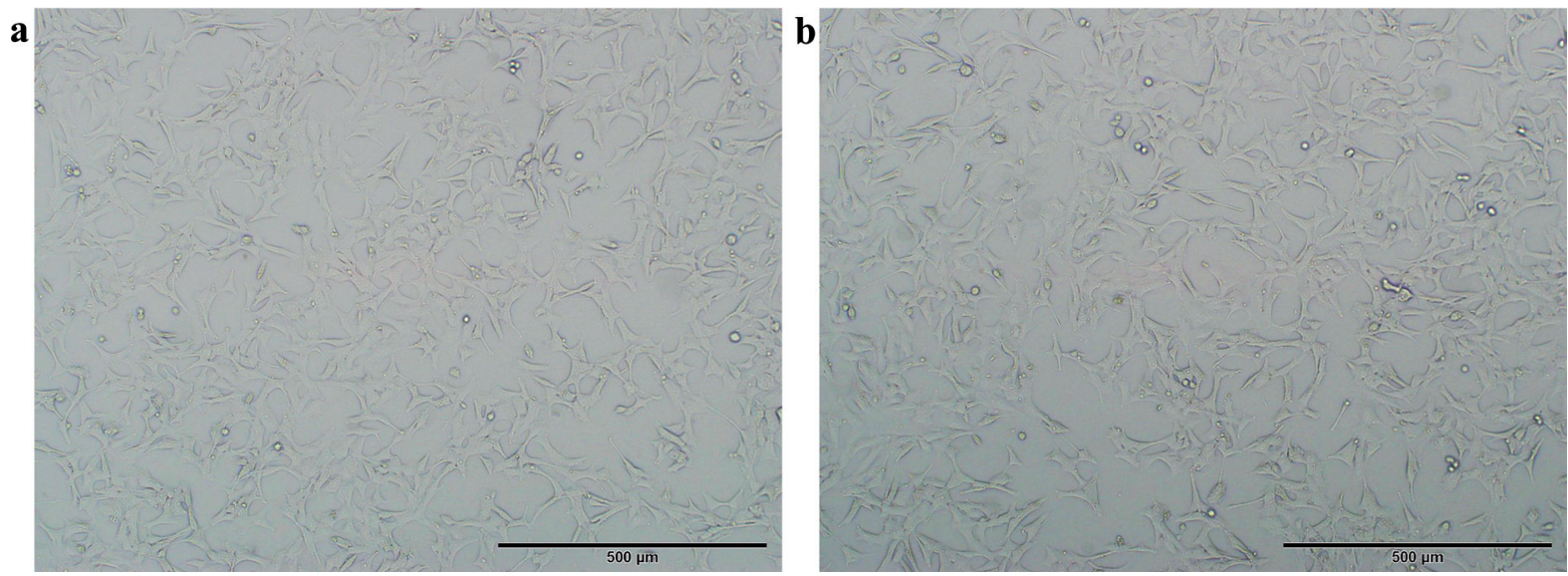

Figure 1. Morphology of A549 before and after in vivo passage. a Morphology of A549 cells. b Morphology of A549 cells after in vivo passage. No difference is observed from cell morphology. Scale bar indicated $500 \mu \mathrm{m}$. (Original magnification: $\times 100)$

$10 \mathrm{sec}$. Beta-actin was used as internal control. Relative expression levels of the genes were calculated using the $\Delta \Delta \mathrm{CT}$ method.

In vivo analysis of lung cancer metastasis in nude mice. A549 $\mathrm{CD}_{133^{+}}$cells were harvested, washed with PBS and resuspended in PBS diluted matrigel. For subcutaneous injection, $10^{5}$ cells were injected into the armpit of mice $(\mathrm{n}=$ 26, xenograft group) and for tail vein injection, $5 \times 10^{4}$ A549 $\mathrm{CD}_{133^{+}}$cells suspended in PBS for each mice $(\mathrm{n}=8)$. Saline as control were injected subcutaneously into the armpit of mice $(n=4)$. All mice were anesthetized and killed by cardiac blood collection on day 31 after injection respectively. Brain, heart, lung, liver, spleen, kidney and tumor from each nude mouse were collected and metastasis nodules counted by gross, stored at $-70{ }^{\circ} \mathrm{C}$. Half of the organs were fixed with $4 \%$ paraformaldehyde.

Histopathological analysis. Different organs of the nude mice fixed with $4 \%$ paraformaldehyde were embedded in paraffin. The tissue was cut in thin sections $(4 \mu \mathrm{m})$, stained with hemotoxylin and eosin ( $\mathrm{HE})$ and then evaluated.

Serological test. The nude mice were anesthetized with an intraperitoneal injection of $50 \mathrm{mg} / \mathrm{kg}$ pentobarbital sodium, and blood sample was collected from the left cardiac ventricle of the nude mice with $1 \mathrm{ml}$ syringe (BD, USA). The blood was then transferred into an anticoagulant tube, $4{ }^{\circ} \mathrm{C} 1000 \times$ g centrifugation for $15 \mathrm{~min}$, the supernatant as plasma was removed to an new Eppendorf tube, store at $-20^{\circ} \mathrm{C}$.

Plasma $\alpha$-fetoprotein (AFP) level is measured with Mouse Alpha Fetoprotein Elisa Assay Kit (Nanjing Jiancheng Bioengineering Institute, Nanjing, China), glutamic-pyruvic transaminase (GPT) level is measured with Glutamic-pyruvic Transaminase Kit (Nanjing Jiancheng Bioengineering Institute, Nanjing, China) and glutamic- oxaloacetic transaminase (GOT) level is measured with Glutamic- oxaloacetic Transaminase Kit (Nanjing Jiancheng Bioengineering Institute, Nanjing, China).
Statistical analysis. Results are expressed as Mean \pm S.E. Statistical analysis was performed using Student's t test or a 1way or 2 -way analysis of variance (ANOVA) test. $P<0.05$ was considered to be statistically significant.

\section{Results}

Isolation and culture of A549 $\mathrm{CD} 133^{+}$cells from A549 cells. In order to make the A549 cell line more resemble to the original primary tumor, the xenografted tumor was harvested and cultured in vitro. A549 cells which have been passaged in vivo were observed under microscope with no difference on cell morphology with A549 cell line. (Fig.1)

$\mathrm{A} 549 \mathrm{CD} 33^{+}$cells were sorted by flow cytometry and the positive rate was about $1.8 \%$ (Fig.2).

A549 CD $133^{+}$cells were cultured in SFM and grew in floating tumor spheres. When passaged in the same medium the spheres were digested into single cells and the tumor spheres reformed about 10 days later. However, A549 cells grew as adherent cells in F12 containing 10 \% FBS, even after several passages, there were no spheres detected.

Sphere formation of $\mathrm{A} 549 \mathrm{CD} 33^{+}$and A549 cells. Significance difference is found in sphere formation between the two cell lines. CD $133^{+}$cells from A549 cells formed tumor spheres in 3 week, meanwhile no tumor sphere were found in A549 cells. The clonies from single A549 CD133+ cell containing approximately 15-500 cells, yet single A549 cell are observed. Numbers of the clone spheres of A549 and A549 CD133 ${ }^{+}$cells were 0 and $24.3 \pm 8.25(P<0.05)$ respectively.

Migration potential of A549 cells and A549 CD133 cells. In order to investigate the migration capacity of A549 and $\mathrm{A} 549 \mathrm{CD} 133^{+}$cells, an in vitro migration assay was carried out and results are shown in Fig.3a. The average numbers of invaded cells across the membranes were $84.21 \pm$ 4.17 and $91.90 \pm 1.22(P<0.05)$ for A549 and A549 CD133 ${ }^{+}$ cells, respectively. 

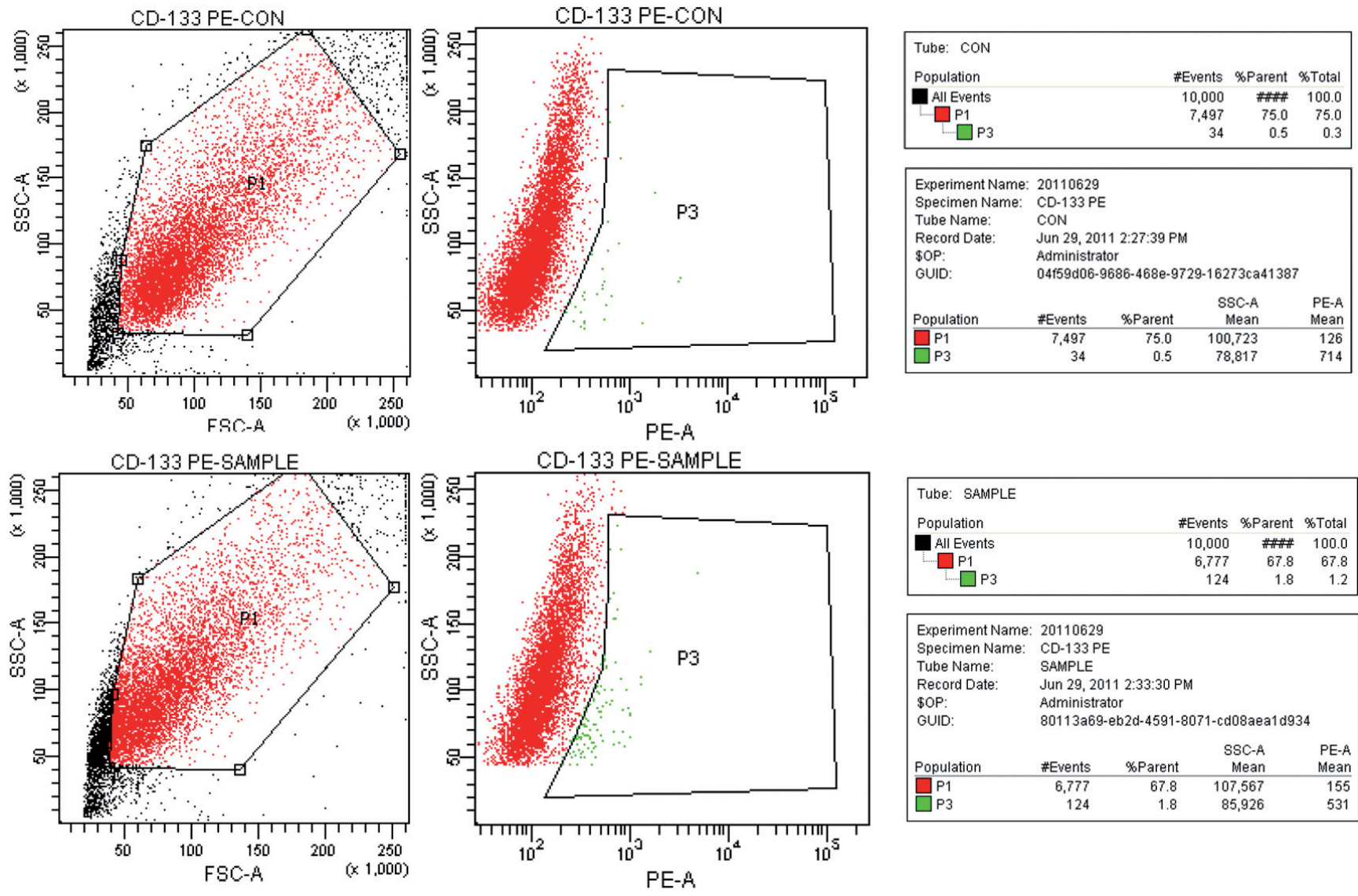

Experiment Name: 20110629

Specimen Name: CD-133 PE

Tube Name: SAMPLE

Record Date: Jun 29, 2011 2:33:30 PM

\$OP: $\quad$ Administrator

GUID: $\quad$ 80113a69-eb2d-4591-8071-cd08aea1d934

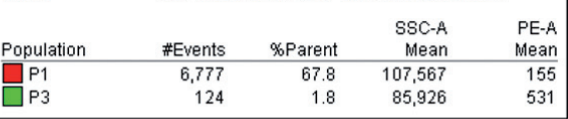

Figure 2. Flow cytometry sorting of A549 CD133 positive cells. The percent of A549 CD133 ${ }^{+}$cells in A549 cell line was about $1.8 \%$.

Invasion potential measurement of A549 cells and A549 $\mathrm{CD}^{133}{ }^{+}$cells. The in vitro invasion capacity of A549 and A549 $\mathrm{CD} 133^{+}$cells were carried out and the results are shown in Fig. 3 b A549 and A549 CD133 cells invasion through the matrigel from the upper to the lower chamber in majority of cells, the average numbers of invaded cells across the membranes were $82.94 \pm 1.69$ and $93.35 \pm 2.03(P<0.01)$ for A549 and A549 $\mathrm{CD} 133^{+}$cells, respectively.

Real-time quantitative PCR analysis of A549 cells and A549 $\mathrm{CD} 133^{+}$cells. $\triangle \Delta \mathrm{CT}$ method was applied to genes VEGF-A, VEGF-B, MMP-2 for the Real-time quantitative PCR. As shown in Fig.3c, VEGF-A, VEGF-B were greatly increased in $\mathrm{A} 549 \mathrm{CD} 133^{+}$cells compared to that in A549 cells while the expression of MMP-2 were decreased. The expression of VEGF-A and VEGF-B in A549 CD133+ cells increased about 5 folds. This result indicated VEGF-A and VEGF-B might play important role in liver metastasis of lung adenocarcinoma.

In vivo analysis of lung cancer metastasis in nude mice. In our experiment, liver metastasis was found in 22 mice of matrigel group. Meanwhile five in eight mice of the tail veil group were found with liver metastasis. The liver metastasis rate is $79.41 \%$. Spleen metastasis was only found in 1 mice of matrigel group with a spleen metastasis rate of $2.94 \%$. Other organs were not observed metasrasis.

Gross and histological examination of normal liver and liver metastasis sites were showed in Fig.4.

HE stain revealed that liver tissue with metastatic tumor cell exhibited a very clear difference in liver cell hystologic appearances compared with normal liver tissue. Severe damage of liver is displayed in the xenograft group and tumor cell could be seen invaded in the liver. Morphological characteristics of tumor cells are nuclei hyperchromatic, big cytoplasm and inversion ratio of nucleus/cytoplasm. The invasion of tumor cells formed little clumps or balls or in small nodular, with cell debris distributed in the intermediate zone. Tumor invasion caused degenerative and necrotic changes of hepatic cells, accompanied by the proliferation of liver cells with large and empty nucleus. Infiltration of tumor cells also induced the fibroblasts proliferation, thereby restricted the invasion of tumor cell.

Plasma AFP, GPT and GOT level between liver metastasis in mice and control mice

Since the high liver metastasis rate of in vivo assays, we performed plasma AFP, GPT and GOT detection. Fig.5a displayed that the slight increase of AFP was detected in xe- 
a

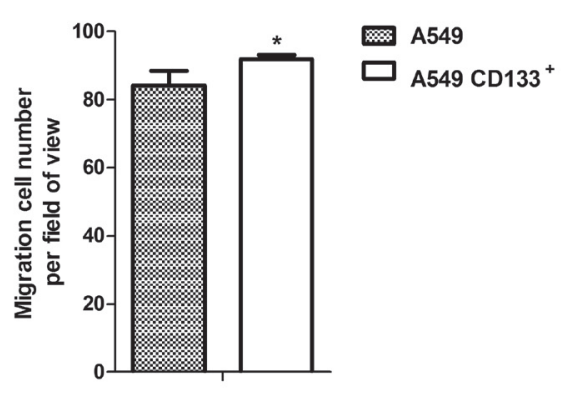

$24 \mathrm{~h}$

C

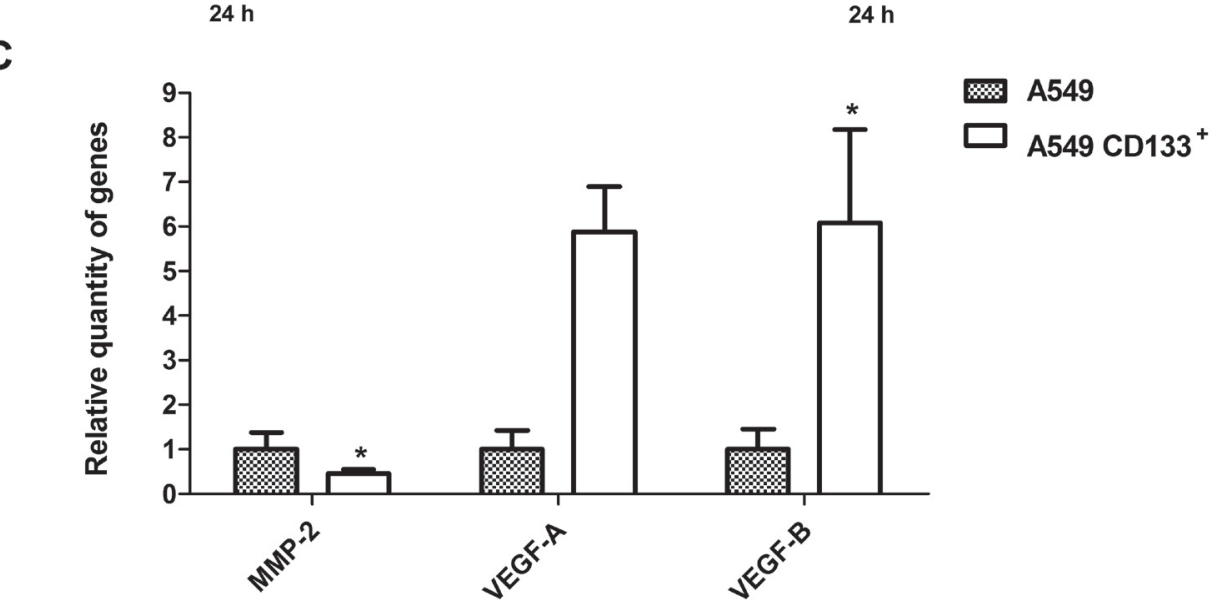

b

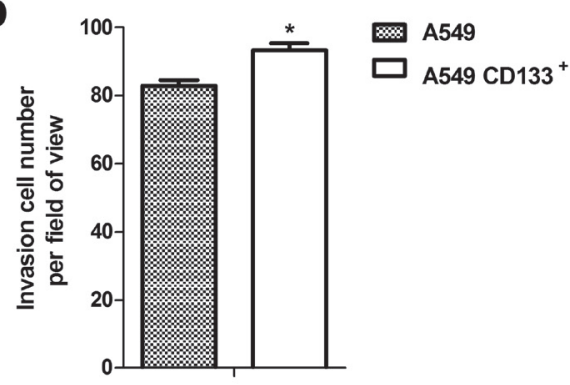

$24 \mathrm{~h}$

Figure 3. In vitro assays of A549 cells and A549 CD133 ${ }^{+}$cells. a In vitro migration of A549 cells and A549 CD133 ${ }^{+}$cells. Cells were cultured in F12 serum free medium in upper well of the Transwell chamber for $24 \mathrm{~h}$. Data is expressed as Mean \pm S.E, ${ }^{\star} P<0.05$. b Invasion potential of A549 and A549 $\mathrm{CD}_{133}{ }^{+}$cells. Data is expressed as Mean \pm S.E, ${ }^{*} P<0.01$. $\mathrm{c}$ Expression changes of genes in A549 $\mathrm{CD} 133^{+}$cells. Real-time PCR was performed on A549 cells and $\mathrm{A549} \mathrm{CD}_{133^{+}}$cells. The expression of MMP-2, VEGF-A and VEFG-B were determined in A549 CD133 cells compared to that of A549 cells using Delta-Delta CT method. Data were expressed as Mean \pm S.E. ${ }^{*} P<0.01$, significant difference between A549 cells and A549 CD133 ${ }^{+}$cells.
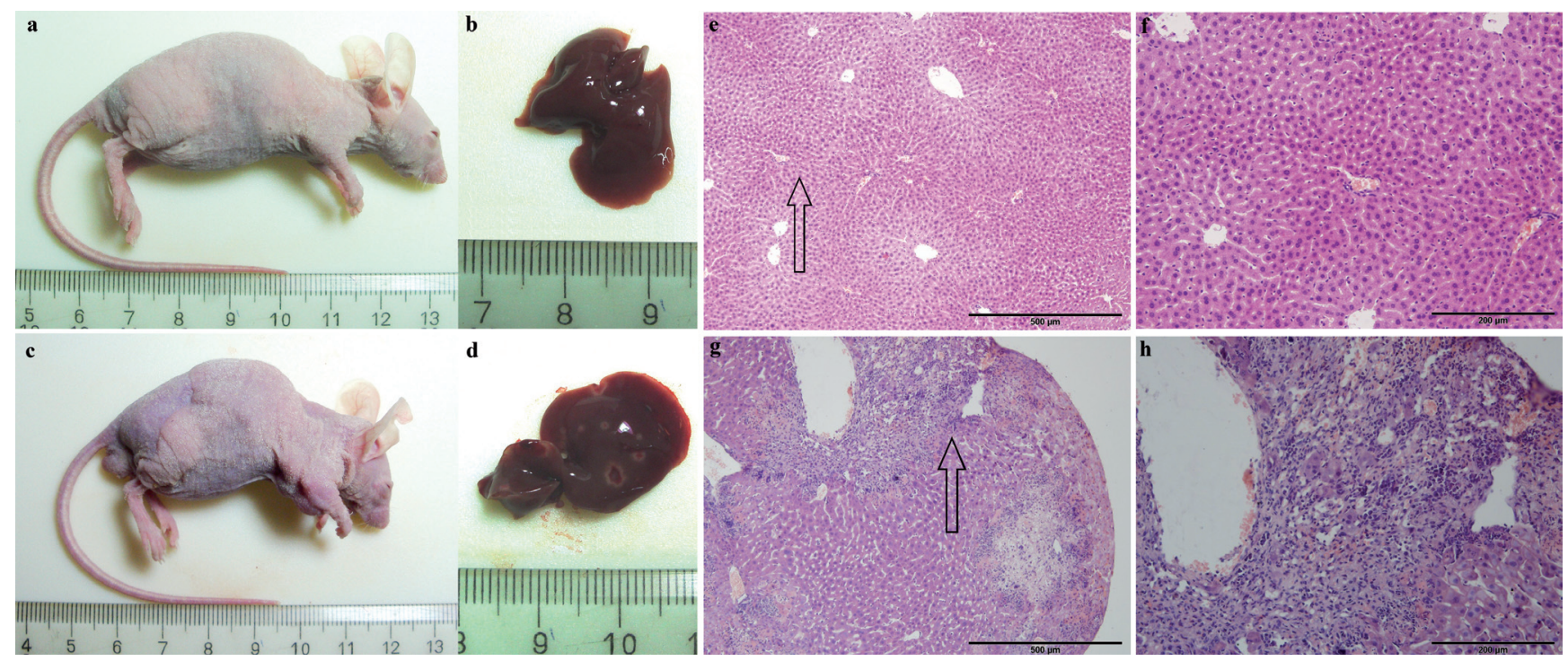

Figure 4. Gross and histological examination of liver. a, b Gross examination of mice and liver in control group, c, $d$ gross examination of mice and liver in xenograft group, the white spots were indicated as metastatic nodules that formed on the surface of the liver. e, f Histological examination of the livers with HE staining in control group, f showed magnified areas of the indicated arrowheads of e. $g$, h Histological examination of the livers with HE staining in xenograft group, $h$ showed magnified areas of the indicated arrowheads of magnified areas of the indicated arrowheads of g. Scale bar indicated $500 \mu \mathrm{m}$ for $\mathrm{e}$ and $\mathrm{g}$ (Original magnification: $\times 100)$ and $200 \mu \mathrm{m}$ for $\mathrm{f}$ and $\mathrm{h}($ Original magnification: $\times 200)$. 

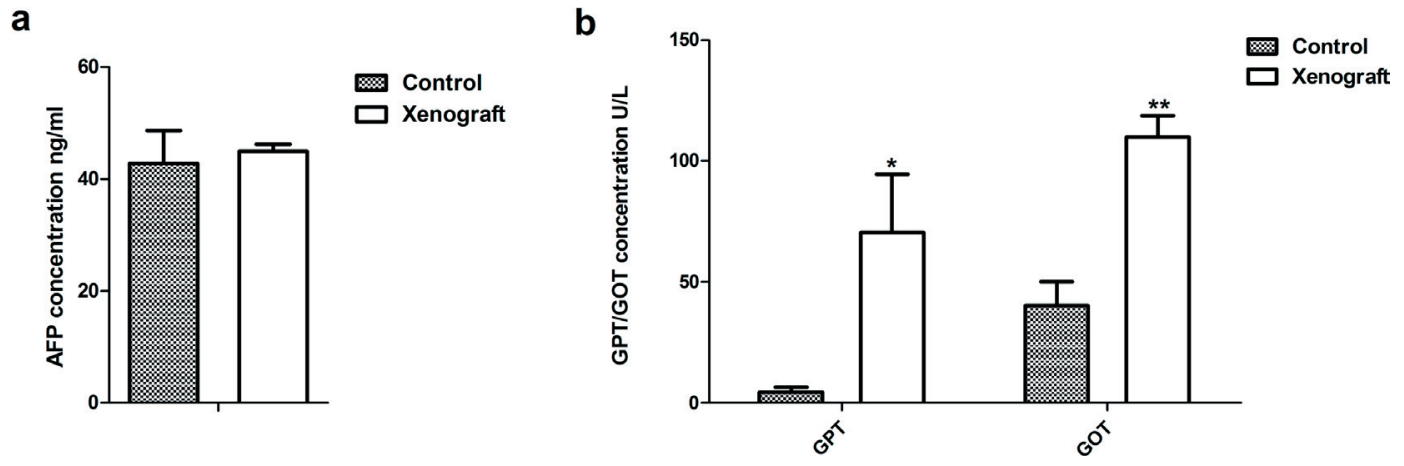

Figure 5. Plasma AFP, GPT and GOT level of metastasis mice and control mice. a AFP concentration in plasma of liver metastatic mice compared to the control mice. b Plasma GPT and GPT concentration in different groups of mice. Data is expressed as Mean \pm S.E. ${ }^{\star} P<0.05,{ }^{\star *} P<0.01$ (n $=10$ ), significant difference between control group and xenograft group.

nograft group compared to the control group. Concentration of GPT and GOT in mice plasma were shown in Fig.5b which indicate that both the GPT and GOT of xenograft group were about 11.3 folds and 2.7 folds higher than those of the control group respectively.

\section{Discussion}

Lung cancer is one of the most mortal malignant diseases in the world with NSCLC accounting for $80 \%$ of lung cancer. Current treatment such as chemotherapy have poor efficacy largely due to the recurrence and metastasis of lung cancer. Liver metastasis of lung cancer is very common. However, lung cancer cell model of liver metastasis is rarely seen. In our study, we identified a cell subpopulation isolated from A549 cell line exhibited high liver metastatic potential, which was the first report of a lung cancer liver metastasis model.

Our results showed that CD133+ cells isolated from A549 cells by flow cytometry which accounting for a small percentage of A549 cells at $1.8 \%$ which was consistent with previous reports, where the proportion was between $0.98 \% \sim 3.9 \%$ $[10,16,17]$. The tumorigenicity of the tumor cell lines was enhanced after in vivo passage which was reported in previous studies [18-21]. A in invo passage strategy was also adopted in present study. A549 CD $133^{+}$cells exhibited significantly higher sphere-forming, migration and invasion abilities than their counterpart A549 cells, with high expression levels of VEGF-A, VEGF-B. Since CD $133^{+}$cells were sorted from the A549 cells which also have been in vivo passaged, we thought the difference between $\mathrm{CD} 133^{+}$cells and A549 cells may be due to unique characteristic of $\mathrm{CD}_{133^{+}}$cells [22-24]. It need to be noticed that Meng et al studied the CD133+ and CD133- A549 cells and found that they exhibited similar abilities of colony formation, invasion [16]. The difference may lie in two aspects: firstly, they use the sub-cloning method to acquire the cells for colony formation and tumorigenicity assay, which have been screened with high ability in forming colonies and was nearly no correlation with the marker they expressed; Secondly, the obtained A549 CD133 ${ }^{+}$cells in our study were cultured and maintained in serum-free medium supplemented with B27 and A549 cells and cultured in a medium containing serum. Since culturing condition is very important for the stem cells to maintain their properties, it may be a critical factor to bring about contradictory results.

Among the examined genes, only MMP-2 showed decreased expression in A549 CD133 ${ }^{+}$cells, the other two genes were elevated. Angiogenesis plays an important role in the progression and metastasis of solid tumors. VEGF is a potent proangiogenic growth factor expressed by most cancer cell types [25]. VEGF stimulates endothelial cell proliferation, migration and tube formation [26]. In fact, tumor growth beyond $1 \pm 2 \mathrm{~mm}^{3}$ which contributes to the metastatic process carrying cancer cells into the circulation is strictly dependent on angiogenesis [27]. The over expressed genes showed that A549 CD $133^{+}$cells had characters of angiogenesis which correlated with its ability of liver metastasis.

In vivo results indicated high liver metastasis potential of $\mathrm{A} 549 \mathrm{CD} 133^{+}$cells at a metastasis rate of $79.41 \%$. Histopathological and serological studies also supported the outcomes of liver metastasis.

Hepatic carcinoma is one of the common reasons cause high AFP which is important in the diagnosis of hepatic carcinoma (HCC)[28]. Presented results showed that AFP level was only slightly elevated. Significant elevated AFP was commonly seen in primary hepatoma patient, indicating there was different mechanism between metastatic hepatoma and primary hepatoma. Elevation of serum hepatic enzymes such as GPT and GOT are important diagnostic proprognosis indexes for liver injury and predictive of death associated with liver disease and hepatoma [29,30]. GPT is found primarily in the liver cell cytoplasm, intracellular 1000-3000 times higher than the serum concentration. As long as $1 \%$ of the liver cells are destroyed, GPT will be doubled increased. Therefore, GPT is recommended by the World Health Organization as the most sensitive detection indicators of liver dysfunction. In our study the GPT in A549 CD133 model was 11.3 times higher than that 
of the control group indicating the liver damage. GOT mainly distributed in the mitochondria and cytoplasm of liver cells. The serum GOT level in xenograft group was 2.7 times higher than that of control group. This serological result is consistent with our histopathological studies.

Several animal models for lung cancer metastasis have been reported during these years such as systemic metastasis models, bone-specific metastasis model and so on [31-35]. Moreover, high-skilled operation such as cardiac injection and tail vein injection are needed, which was accompanied by high animal mortality and lower success rate [35-37]. With regard to the $\mathrm{A} 549 \mathrm{CD} 133^{+}$cells, it could be easily obtained through flow cytometry and cells inoculated subcutaneously in nude mouse could be employed to establish spontaneous liver metastasis model. Obviously, the method is more simple and efficient with low mortality. Our results showed A549 CD133+ cells induced a high liver metastasis rate $(\sim 80 \%)$ which indicated the good quality of liver metastasis and was supported by the histopathological analysis and serological test. But it should be stressed that quality control is the key in proposing a new model, more researches are needed to establish the corresponding standard to evaluate this model.

\section{Conclusion}

To our knowledge, it is the first report of liver metastasis potential of $\mathrm{A} 549 \mathrm{CD} 133^{+}$cells. Our present data demonstrated that $\mathrm{A} 549 \mathrm{CD} 133^{+}$cells exhibited high liver metastasis potential consistent with the severe liver cell damage in pathological examination and serological tests of plasma GPT and GOT results. It may provide a new method for study of liver metastasis of lung adenocarcinoma.

Acknowledgements: This study was supported by National Basic Research Program of China (973 Program, 2010CB934002).

\section{References}

[1] KOHLER BA, WARD E, MCCARTHY BJ, SCHYMURA MJ, RIES LAG et al. Annual report to the nation on the status of cancer, 1975-2007, featuring tumors of the brain and other nervous system. J Natl Cancer Inst 2011; 103: 714-736. http:// dx.doi.org/10.1093/jnci/djr077

[2] SIEGEL R, NAISHADHAM D, JEMAL A. Cancer statistics, 2012. CA Cancer J Clin 2012; 62: 10-29. http://dx.doi. org/10.3322/caac. 20138

[3] SALAH S, TANVETYANON T, ABBASI S. Metastatectomy for extra-cranial extra-adrenal non-small cell lung cancer solitary metastases: systematic review and analysis of reported cases. Lung Cancer 2012; 75: 9-14. http://dx.doi.org/10.1016/ j.lungcan.2011.07.014

[4] IGUCHI H, TANAKA S, OZAWA Y, KASHIWAKUMA T, KIMURA T et al. An experimental model of bone metastasis by human lung cancer cells: the role of parathyroid hormonerelated protein in bone metastasis. Cancer Res 1996; 56: 4040-4043.
[5] LEDUC EH. Metastasis of transplantable hepatomas from the spleen to the liver in mice. Cancer Res 1959; 19: 1091-1095.

[6] MORIKAWA K, WALKER SM, JESSUP JM, FIDLER IJ. In vivo selection of highly metastatic cells from surgical specimens of different primary human colon carcinomas implanted into nude mice. Cancer Res 1988; 48: 1943-1948.

[7] MORIKAWA K, WALKER SM, NAKAJIMA M, PATHAK $S$, JESSUP JM et al. Influence of organ environment on the growth, selection, and metastasis of human colon carcinoma cells in nude mice. Cancer Res 1988; 48: 6863-6871.

[8] KYRIAZIS AP, DIPERSIO L, MICHAEL GJ, PESCE AJ, STINNETT JD. Growth patterns and metastatic behavior of human tumors growing in athymic mice. Cancer Res 1978; 38: 3186-3190.

[9] CHARAFE-JAUFFRET E, GINESTIER C, IOVINO F, WICINSKI J, CERVERA $\mathrm{N}$ et al. Breast cancer cell lines contain functional cancer stem cells with metastatic capacity and a distinct molecular signature. Cancer Res 2009; 69: 1302-1313. http://dx.doi.org/10.1158/0008-5472.CAN-08$\underline{2741}$

[10] ERAMO A, LOTTI F, SETTE G, PILOZZI E, BIFFONI M et al. Identification and expansion of the tumorigenic lung cancer stem cell population. Cell Death Differ 2008; 15: 504-514. http://dx.doi.org/10.1038/sj.cdd.4402283

[11] MA S, CHAN K-W, HU L, LEE TK-W, WO JY-H et al. Identification and characterization of tumorigenic liver cancer stem/progenitor cells. Gastroenterology 2007; 132: 2542-2556. http://dx.doi.org/10.1053/j.gastro.2007.04.025

[12] RICCI-VITIANI L, LOMBARDI DG, PILOZZI E, BIFFONI $\mathrm{M}$, TODARO $\mathrm{M}$ et al. Identification and expansion of human colon-cancer-initiating cells. Nature 2007; 445: 111-115. http://dx.doi.org/10.1038/nature05384

[13] SINGH SK, HAWKINS C, CLARKE ID, SQUIRE JA, BAYANI $J$ et al. Identification of human brain tumour initiating cells. Nature 2004; 432: 396-401. http://dx.doi.org/10.1038/ nature 03128

[14] JORDAN CT, GUZMAN ML, NOBLE M. Cancer stem cells. N Engl J Med 2006; 355: 1253-1261. http://dx.doi.org/10.1056/ NEJMra061808

[15] REYA T, MORRISON SJ, CLARKE MF, WEISSMAN IL. Stem cells, cancer, and cancer stem cells. Nature 2001; 414: 105-111. http://dx.doi.org/10.1038/35102167

[16] MENG X, LI M, WANG X, WANG Y, MA D. Both CD133+ and CD133- subpopulations of A549 and H446 cells contain cancer-initiating cells. Cancer Sci 2009; 100: 1040-1046. http://dx.doi.org/10.1111/j.1349-7006.2009.01144.x

[17] TIRINO V, CAMERLINGO R, BIFULCO K, IROLLO E, MONTELLA R et al. TGF- $\beta 1$ exposure induces epithelial to mesenchymal transition both in CSCs and non-CSCs of the A549 cell line, leading to an increase of migration ability in the CD133+ A549 cell fraction. Cell Death Dis 2013; 4: e620. http://dx.doi.org/10.1038/cddis.2013.144

[18] YANG B, TUO S, TUO C, ZHANG N, LIU Q. Highly metastatic nude mouse model of human primary gastric lymphoma constructed by surgical orthotopic transplantation and in vivo continuous screening method. Zhonghua Yi Xue Za Zhi 2010; 90: 413-417. 
[19] BOGOEVA MV. Changes in growth characteristics of mouse ascites tumor AISM during the process of passage in vivo. Biull Eksp Biol Med 1990; 109: 176-177.http://dx.doi.org/10.1007/ $\underline{B F 00841677}$

[20] YANG B, TUO S, TUO C, ZHANG N, LIU Q. A murine model of human primary hepatic lymphoma constructed by surgical orthotopic implantation of histologically intact human tumor tissue and in vivo continuous orthotopic passage. Zhonghua Yi Xue Za Zhi 2012; 92: 1569-1572.

[21] LAW LW. Changes in tumor-specific antigen expression during passage in vitro and in vivo of newly derived methylcholanthrene-induced sarcomas of BALB/C mice. Int J Cancer 1980; 25: 251-259. http://dx.doi.org/10.1002/ ijc. 2910250213

[22] HILBE W, DIRNHOFER S, OBERWASSERLECHNER F, SCHMID T, GUNSILIUS E et al. CD133 positive endothelial progenitor cells contribute to the tumour vasculature in non-small cell lung cancer. J Clin Pathol 2004; 57: 965-969. http://dx.doi.org/10.1136/jcp.2004.016444

[23] TIRINO V, CAMERLINGO R, FRANCO R, MALANGA $\mathrm{D}$, ROCCA AL et al. The role of CD133 in the identification and characterisation of tumour-initiating cells in non-smallcell lung cancer. Eur J Cardiothorac Surg 2009; 36: 446-453. http://dx.doi.org/10.1016/j.ejcts.2009.03.063

[24] BERTOLINI G, ROZ L, PEREGO P, TORTORETO M, FONTANELLA et al. Highly tumorigenic lung cancer CD133+ cells display stem-like features and are spared by cisplatin treatment. Proc. Natl. Acad. Sci. U. S. A 2009; 106: 16281-16286. http://dx.doi.org/10.1073/pnas.0905653106

[25] FERRARA N, HILLAN KJ, GERBER H-P, NOVOTNY W. Discovery and development of bevacizumab, an anti-VEGF antibody for treating cancer. Nat Rev Drug Discov 2004; 3: 391-400. http://dx.doi.org/10.1038/nrd1381

[26] DE VRIES C, ESCOBEDO JA, UENO H, HOUCK K, FERRARA $\mathrm{N}$ et al. The fms-like tyrosine kinase, a receptor for vascular endothelial growth factor. Science 1992; 255: 989-991. http://dx.doi.org/10.1126/science.1312256

[27] KODAMA J, SEKI N, TOKUMO K, HONGO A, MIYAGI Y et al. Vascular endothelial growth factor is implicated in early invasion in cervical cancer. Eur J Cancer 1999; 35: 485-489. http://dx.doi.org/10.1016/S0959-8049(98)00410-9

[28] ARGUEDAS MR, CHEN VK, ELOUBEIDI MA, FALLON MB. Screening for hepatocellular carcinoma in patients with hepatitis $\mathrm{C}$ cirrhosis: a cost-utility analysis. Am J
Gastroenterol 2003; 98: 679-690. http://dx.doi.org/10.1111/ j.1572-0241.2003.07327.x

[29] ALATALO P, KOIVISTO H, PUUKKA K, HIETALA J, ANTTILA $P$ et al. Biomarkers of liver status in heavy drinkers, moderate drinkers and abstainers. Alcohol Alcohol 2009; 44: 199-203. http://dx.doi.org/10.1093/alcalc/agn099

[30] TARGHER G. Elevated serum gamma-glutamyltransferase activity is associated with increased risk of mortality, incident type 2 diabetes, cardiovascular events, chronic kidney disease and cancer - a narrative review. Clin Chem Lab Med 2010; 48: 147-157. http://dx.doi.org/10.1515/ CCLM.2010.031

[31] KONDO K, FUJINO H, MIYOSHI T, ISHIKURA H, SAKIYAMA S et al. Orthotopically implanted SCID mouse model of human lung cancer suitable for investigating metastatic potential and anticancer drug effects. Oncol. Rep 2004; 12: 991-999.

[32] HOWARD RB, MULLEN JB, PAGURA ME, JOHNSTON MR. Characterization of a highly metastatic, orthotopic lung cancer model in the nude rat. Clin. Exp Metastasis 1999; 17: 157-162. http://dx.doi.org/10.1023/A:1006637712294

[33] ZHANG X, WU J. Establishing of the Transplanted Animal Models for Human Lung Cancer. J Nanjing Med Univ 2009; 23: 1-5. http://dx.doi.org/10.1016/S1007-4376(09)60017-4

[34] LI M, ZHOU M, GONG M, MA J, PEI F et al. A novel animal model for bone metastasis in human lung cancer. Oncol Lett 2012; 3: 802-806.

[35] YANG S, DONG Q, YAO M, SHI M, YE J et al. Establishment of an experimental human lung adenocarcinoma cell line SPC-A-1BM with high bone metastases potency by $(99 \mathrm{~m}) \mathrm{Tc}$ MDP bone scintigraphy. Nucl Med Biol 2009; 36: 313-321. http://dx.doi.org/10.1016/j.nucmedbio.2008.12.007

[36] MIKI T, YANO S, HANIBUCHI M, KANEMATSU T, MUGURUMA $\mathrm{H}$ et al. Parathyroid hormone-related protein (PTHrP) is responsible for production of bone metastasis, but not visceral metastasis, by human small cell lung cancer SBC-5 cells in natural killer cell-depleted SCID mice. Int J Cancer 2004; 108: 511-515. http://dx.doi.org/10.1002/ ijc. 11586

[37] IGUCHI H, ONUMA E, SATO K, SATO K, OGATA E. Involvement of parathyroid hormone-related protein in experimental cachexia induced by a human lung cancer-derived cell line established from a bone metastasis specimen. Int J Cancer J 2001; 94: 24-27. http://dx.doi.org/10.1002/ijc.1425 